\title{
Gill structure of cultured Salmo trutta fario related to sampling techniques
}

\author{
S. Crespo ${ }^{1}$, F. Padros ${ }^{1}$, R. Sala ${ }^{2}$, M. J. Marlasca ${ }^{1}$ \\ ${ }^{1}$ Laboratorio de Biologia, Facultad de Veterinária, U. A. B., Bellaterra, Barcelona, Spain \\ ${ }^{2}$ Laboratorio de Nutrición, Facultad de Veterinária, U. A. B., Bellaterra, Barcelona, Spain
}

\begin{abstract}
A scanning electron microscope and histological study of the trout Salmo trutta fario gill was undertaken following 3 different killing techniques (concussion, decapitation and prolonged anesthesia with MS 222) and 2 different fixation procedures (glutaraldehyde and formaldehyde). Fifty $\%$ of fish killed by concussion and $20 \%$ of fish sacrificed by decapitation displayed gill lamellar dilations (telangiectasis), whereas no anesthetized fish showed altered gill structure. No differences could be detected when comparing the effects of the 2 fixatives. We conclude that salmonids should not be killed either by concussion or decapitation if gills are to be examined histologically.
\end{abstract}

The fish gill is very sensitive to physical and chemical alterations of the aquatic medium. Hocutt \& Tilney (1985) have described gill lesions (oedema, epithelial desquamation and fusion of lamellae) caused by heat. Pollution (acid stress, un-ionized ammonia, heavy metals, pesticides, etc.) has been shown to alter chloride cell structure and induce lamellar epithelium desquamation and/or filament epithelium hyperplasia (Leino \& McCormick 1984, Soderberg et al. 1984, Crespo \& Sala 1986, Sinhaseni \& Tesprateed 1987). There is a close relationship between gill morphological alterations and stress (Peters \& Hong 1985) or lack of polyunsaturated fatty acids in the diet (Bell et al. 1985), and several infectious agents have been described in association with proliferative gill diseases and gill necrosis (Kovács-Gayer 1984, Daoust \& Ferguson 1985). Gill morphology is therefore a good indicator of the water quality and the general health condition of cultured fish (Peters et al. 1984).

Telangiectasis (gill lamellar dilations) has been reported by several authors as a consequence of $\mathrm{NH}_{3}$ exposure in channel catfish Ictalurus punctatus and rainbow trout Salmo gairdneri (Smart 1976, Soderberg et al. 1984, Soderberg 1985). Recently, Herman \& Meade (1985) proved that appearance of telangiectasis in the gill lamellae of lake trout Salvelinus namaycush was due to the method used to kill the fish. However, results were somewhat controversial since other salmonid species (Salmo salar and S. gairdneri) were not affected by killing techniques. Hughes (1979) suggested that some of the undulations on the rainbow trout gill lamellae viewed in the scanning electron microscope (which corresponded to telangiectasis) might be related to contraction during fixation.

The purpose of the present study was to investigate the effects of concussion (a sharp blow on the skull), decapitation and prolonged anesthesia with MS 222 on the gill structure of cultured brown trout Salmo trutta fario and to compare the effects of 2 fixative solutions (glutaraldehyde and formaldehyde).

Fish were obtained from a fish farm of the Department of Natural Environment, Spain (Generalitat de Catalunya), supplied with well-aerated unpolluted running water $\left(\mathrm{pH}=7.7 ; \mathrm{T}=8^{\circ} \mathrm{C}\right)$. Thirty fish of ca 250 to $300 \mathrm{~g}$ body weight were killed following the 3 different methodologies (10 fish per group). The handling procedure before killing was identical for all fishes. Gill arches were immediately removed and placed in fixative solutions: 5 of each group in $5 \%$ glutaraldehyde and the remaining 5 in $10 \%$ formaldehyde, both in $0.1 \mathrm{MNa}$ cacodylate buffer $(\mathrm{pH}=7.3)$. Samples were dehydrated through ethanol series, embedded in hydroxyethyl methacrylate, cut at 3 to $4 \mu \mathrm{m}$, stained with toluidine blue and viewed under the light microscope. At least 15 filaments per gill were studied and telangiectasis in each filament was quantified in serial sections. Some ethanol-dehydrated samples were critical-point dried with liquid $\mathrm{CO}_{2}$, coated with a thin layer of gold and viewed in a Super III A Isi scanning electron microscope.

Single, very small capillary dilations were observed in gill lamellae, independently of sampling techniques. However, these were not considered as true telangiec- 
tasis and could not be seen in the scanning electron microscope. No fish anesthetized with MS 222 displayed an altered gill structure (Fig. 1a). Of the fish killed by concussion, $50 \%$ displayed more than 4 telangiectases per filament (Fig 1b), and of the fish killed by decapitation, $20 \%$ showed lamellar gill dilations. Telangiectasis could be found at the tip of the lamellae or at their base and the pillar cell system. was often completely disrupted (Fig. 2). Neither oedema nor epithelial desquamation were detected in any of the groups. Occasionally, 2 or 3 lamellae were fused but this was not related to sampling techniques. No differences could be detected when comparing the effects of the 2 fixatives, glutaraldehyde and formaldehyde.

From data presented here we may conclude that telangiectasis in Salmo trutta fario is due to trauma, capillary dilations probably being caused by an unusual amount of blood flowing from the afferent branchial artery or by a decreased outflow in the efferent branchial artery when fish are stunned by a blow on the head or decapitated. An acurate diagnosis on the farm or in the wild is necessary to control disease outbreaks. Taking into account that fish are generally killed by concussion or decapitation (Roberts \& Shepherd 1979), histopathological studies might be
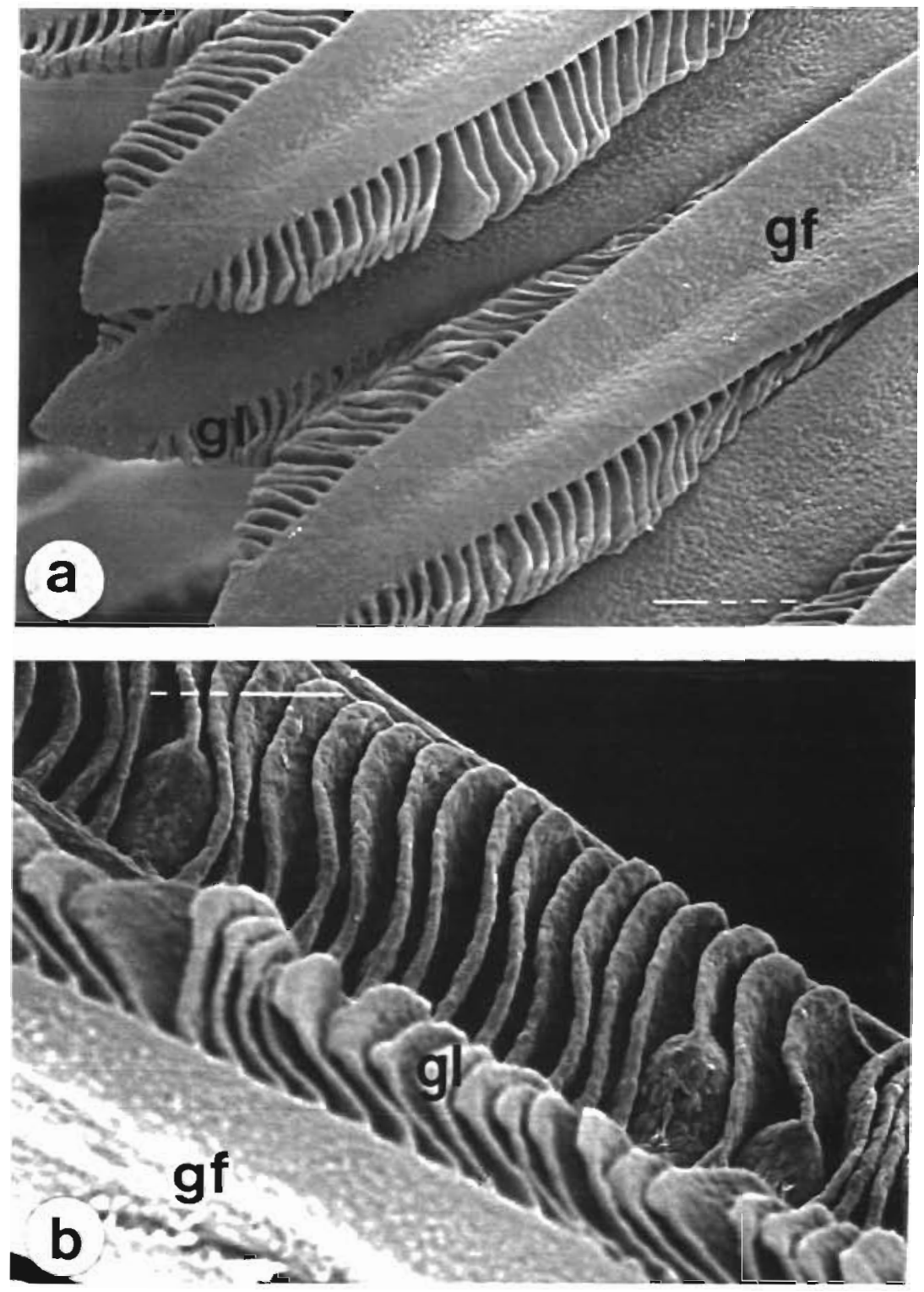

Fig. 1. Salmo trutta fario. Scanning electron micrograph of brown trout gill. (a) Gill filaments (gf) and gill lamellae (gl) of anesthetized trout $(70 \times)$. (b) Telengiectasis at the base of gill lamellae $(\mathrm{gl})$; gf: gill filament $(135 \times)$ 


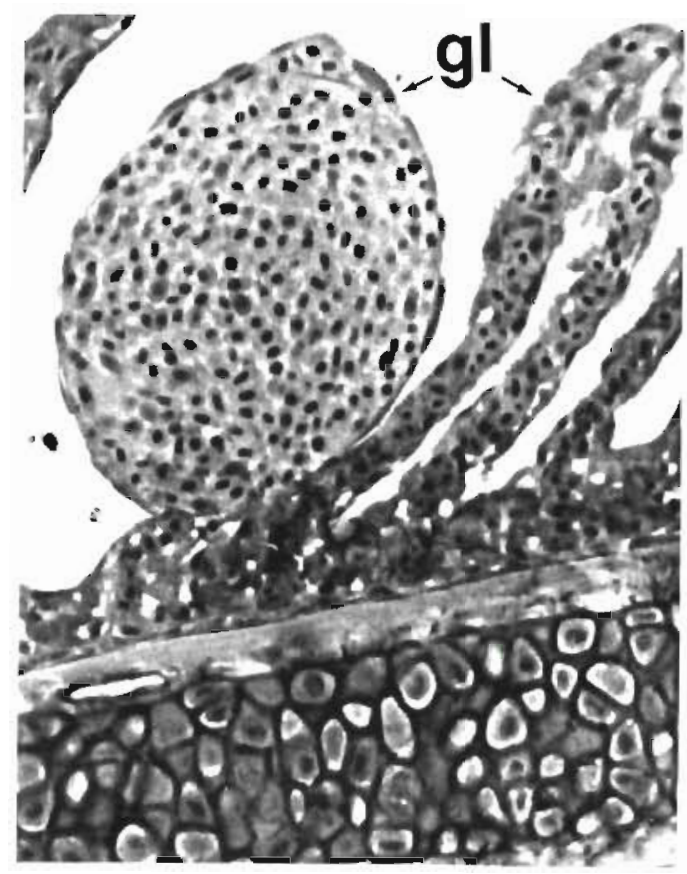

Fig. 2. Salmo trutta fario. Telangiestasis affecting the whole lamella of the trout either stunned by a blow on the head or decapitated $(250 \times)$

misleading. Fish (at least salmonids) should not be killed following traumatic techniques if gills are to be studied histologically.

Acknowledgements. We thank Mr Marino Guillén (Sección Territorial del Medi Natural de la Generalitad de Catalunya) for his invaluable collaboration. This work received financial support from C.A.I.C.Y.T., GR 85-0016

\section{LITERATURE CITED}

Bell, M. V., Henderson, R. J., Pirie, B. J. S., Sargent, J. R. (1985). Growth, gill structure and fatty acid composition of phospholipids in the turbot Scophthalmus maximus in relation to dietary polyunsaturated fatty acid deficiencies In: Cowey, C. B., Mackie, A. M., Bell, J. G. (eds.) Nutrition and feeding in fish. Academic Press, London, p. 365-369

Crespo, S., Sala, R. (1986). Ultrastructural alterations of the dogfish (Scyliorhinus canicula) gill filament related to experimental aquatic zinc pollution. Dis aquat. Org. 1: 99-104

Daoust, P. Y., Ferguson, H. W (1985). Nodular gill disease: a unique form of proliferative gill disease in rainbow trout Salmo gairdneri Richardson. J. Fish Dis. 8: 511-522

Herman, R. L., Meade, J. W. (1985). Gill lamellar dilations (telangiectasis) related to sampling techniques. Trans. Am. Fish. Soc. 114: 911-913

Hocutt, C. H., Tilney, R. L. (1985). Changes in gill morphology of Oreochromis mossambicus subjected to heat stress. Environ. Biol. Fish. 14: 107-114

Hughes, G. M. (1979). Scanning electron microscopy of the respiratory surfaces of trout gills. J. Zool., Lond. 187: $443-453$

Kovács-Gayer, E. (1984). Histophathological differential diagnosis of gill changes with special regard to gill necrosis. In: Olah, J. (ed.) Fish, pathogens and environment in European polyculture. Akadémiai Kiadó, Budapest, p. 219-232

Leino, R. L., McCormick, H. (1984). Morphological and morphometrical changes in chloride cell of the gills of Pimephales promelas after chronic exposure to acid water. Cell Tissue Res. 236: 121-128

Peters, G., Hoffmann, R., Klinger, H. (1984). Environmentalinduced gill disease of cultured rainbow trout (Salmo gairdneri). Aquaculture 38: 105-126

Peters, G., Hong, D. Q. (1985). Gill structure and blood electrolyte levels of European eels under stress. In: A. E. Ellis (ed.) Fish and shellfish pathology. Academic Press, London, p. 183-198

Roberts, R. J., Shepherd, C. J. (1979). Handbook of trout and salmon diseases. Fishing News Books Ltd., Farnham

Sinhaseni, P., Tesprateed, T. (1987). Histopathological effects of paraquat and gill function of Puntius gonionotus Bleeker. Bull. environ. Contam. Toxicol. 38: 308-312

Smart, G. (1976). The effects of ammonia exposure on the structure of rainbow trout Salmo gairdneri. J. Fish Biol. 8: $471-475$

Soderberg, R. W. (1985). Histopathology of rainbow trout Salmo gairdneri Richardson, exposed to diurnally fluctuating un-ionized ammonia levels in static-water ponds. J. Fish Dis. 8: 57-64

Soderberg, R. W. McGee, M. V., Boyd, C. E. (1984). Histology of cultured channel catfish Ictalurus punctatus (Rafinesque). J. Fish Biol. 24: 683-690

Responsible Subject Editor: Professor O. Kinne; accepted for printing on May 10, 1988 